\section{Intracanal Irrigating Solutions Prior to Calcium Hydroxide Medication and Its Effects on Root Dentin Strength}

Leila Clarisse Hillesheim, Juliara Bellina Hoffmann, Daniela Peressoni Vieira Schuldt, Maybell Tedesco, Eduardo Antunes Bortoluzzi, Cleonice Silveira Teixeira
Departament of Dentistry, UFSC

- Universidade Federal de Santa

Catarina, Florianópolis, SC, Brazil

Correspondence: Cleonice Silveira Teixeira, Rua Haroldo Soares Glavan, 929, Condomínio Casa Blanca, casa 16, 88050-005 Florianópolis, SC, Brasil. Tel: +55-048-37215842. e-mail: cleotex@uol.com. br; cleonice.teixeira@ufsc.br

\begin{abstract}
The aim of this study was to assess the effects of intracanal irrigation with sodium hypochlorite $(\mathrm{NaOCl})$ and ethylenediaminetetracetic acid (EDTA) prior to calcium hydroxide medication on the compressive strength of root dentin. Forty-eight roots with single and straight canals were instrumented with a crown-down technique using Flexofile files and Gates Glidden burs, under $0.9 \%$ sodium chloride $(\mathrm{NaCl})$ irrigation. Root canals were randomly separated into 4 groups $(n=12)$, according to the irrigating solution: Control Group, $0.9 \% \mathrm{NaCl}^{\text {; Group }}{ }^{\mathrm{NaOCl}}$, 1\% NaOCl; Group EDTA, 17\% EDTA; and Group ${ }^{\mathrm{EDTA}+\mathrm{NaOCl}}$, 17\% EDTA and $1 \% \mathrm{NaOCl}$. Solutions remained for $40 \mathrm{~min}$, renewed every $10 \mathrm{~min}$, except for Group ${ }^{\mathrm{EDTA}+\mathrm{NaOCl}}$, where the solutions were alternated every $10 \mathrm{~min}$. Canals were dried and filled with calcium hydroxide paste, and radiographed. Each canal was sealed and stored at $37^{\circ} \mathrm{C}$ for 30 days. After this period, the roots were cut $1 \mathrm{~mm}$ below the cementoenamel junction and $6 \mathrm{~mm}$ apically from this point in order to obtain $6 \mathrm{~mm}$-long cylinders. The compressive test was conducted with a crosshead speed of $1 \mathrm{~mm} / \mathrm{min}$. The means $( \pm \mathrm{SD})(\mathrm{MPa})$ of compressive strength were: Control Group, 151.23 \pm 94.36 ; Group ${ }^{\mathrm{NaOCl}}$, 167.50 \pm 57.25 ; Group ${ }^{\text {EDTA }}, 108.79 \pm 99.88$; Group ${ }^{\mathrm{EDTA}+\mathrm{NaOCl}}, 60.12 \pm 92.10$. Significant statistical differences among groups were found (ANOVA and Tukey, $\alpha=5 \%, p=0.02$ ). Control Group and Group ${ }^{\mathrm{NaOCl}}$ showed higher means of compressive strength than Group ${ }^{\mathrm{EDTA}+\mathrm{NaOCl}}$. Intracanal irrigation with 17\% EDTA and $1 \% \mathrm{NaOCl}$ produced a significant reduction of dentin compressive strength 30 days after medication with calcium hydroxide.
\end{abstract}

Key Words: calcium hydroxide, compressive strength, irrigation, sodium hypochlorite.

\section{Introduction}

The endodontic treatment goal is to obtain bacteriafree root canals. The elimination of microorganisms can be achieved using various instrumentation techniques, irrigation solutions and intracanal medicaments (1). Mechanical instrumentation results in the debridement of root canal system, but alone it cannot effectively disinfect root canals, emphasizing the need for an irrigating solution to effectively kill more microorganisms $(2,3)$.

Irrigation is currently the best method for removing pulp tissue remnants and dentin debris during instrumentation (1). Ideally, an irrigating solution should promote debridement, lubrication, dissolve organic tissue and eradicate the microorganisms from the root canal system (4-8). However, sodium hypochlorite is unable to remove inorganic components, and thus, unable to remove the smear layer produced during canal instrumentation $(5,6)$. In an effort to remove the smear layer completely, studies suggest that the canals should be irrigated with ethylenediaminetetracetic acid (EDTA) and $\mathrm{NaOCl}(6,9)$. EDTA is a chelate that acts on the inorganic components of the smear layer. Therefore, irrigation with 15\% EDTA and $1 \% \mathrm{NaOCl}$ removes both inorganic and organic smear layer components (6).

Besides the known importance of employing sodium hypochlorite solution and EDTA during canal instrumentation, and also prior to intracanal medications and canal filling, there has been much discussion over the effects of using these solutions on root dentin strength. In this way, studies have related sodium hypochlorite irrigation with dentin microhardness reduction (10). Other reports correlate sodium hypochlorite with dentin weakening by reduced dentin flexural strength $(3,10,11)$ and elastic modulus $(3,11)$.

EDTA solutions are powerful demineralizing agents, leading to dentinal erosion (9), dentinal tubule enlargement (12) and consequently, decreasing dentin microhardness (13). Higher EDTA concentrations (5\%, 10\% and 15\%) cause greater dentinal erosion (14). Concentrations of EDTA, as low as $1 \%$, may be clinically recommended for removing smear layer adequately and causing less erosion (14). Besides, researchers found that final irrigation with EDTA and $\mathrm{NaOCl}$ for 1, 3 and 5 min was equally efficient on smear layer removal from root dentin walls (6). Another study demonstrated that irrigation with 17\% EDTA for 1 
min, followed by $2.5 \% \mathrm{NaOCl}$ irrigation for another minute, provided the best experimental combination when trying to avoid changes to dentin chemical composition and its morphological structures (15).

For necrotic tissue and microbes, intracanal medication with calcium hydroxide is recommended (2). Meanwhile, root canals treated with calcium hydroxide medication, even for short (16) or long periods (17), may be associated with reduced dentin strength. However, there is little scientific knowledge about the effects of irrigating solutions, like $\mathrm{NaOCl}$ and EDTA, prior to calcium hydroxide medication on root dentin strength. In view of this, the purpose of this study was to evaluate the effect caused by different irrigating solutions, prior to calcium hydroxide intracanal dressing, on root dentin strength. The null hypothesis of this experiment is that the use of different solutions before calcium hydroxide dressing does not affect the root dentin strength in the experimental groups.

\section{Material and Methods}

This study was approved by the institutional Human Ethics Committee (Committee's approval \#2083/2011).

\section{Specimen Selection and Preparation}

Forty-eight intact and single-rooted extracted human mandibular premolars were chosen for the study and stored in $0.1 \%$ thymol solution. The selected teeth were 22 to $25 \mathrm{~mm}$ long. Each tooth was radiographed and carefully examined with a $4 \times$ magnifying glass (Illuminated magnifying glass, Tokyo, Japan) to confirm the existence of a single and straight canal, no cracks and fully formed apical foramen. After cleaning the roots with periodontal curettes, the crowns were removed near of the cementenamel junction with a water-cooled low-speed diamond saw to obtain a standardized root length of $16 \mathrm{~mm}$. The access cavity was made and the roots with large oval canals were replaced in order to avoid canals without round sections after endodontic preparation. The working length (WL) was defined by introducing a \#15 file in the root canal until the tip was observed at the apical foramen, which was subtracted one millimeter from the canal length. Root canals were instrumented with a crown-down technique using Flexofile files (Dentsply Maillefer, Tulsa, OK, USA) until a master apical file size \#50, and Gates Glidden burs \# 4 to \# 1 (Moyco Union Broach, York, PA, USA). Throughout the preparation, canals were irrigated with $2 \mathrm{~mL}$ of $0.9 \%$ sodium chloride solution (Dermus, Florianópolis, SC, Brazil) between every file or bur.

The instrumented canals were dried with absorbent paper points (Dentsply Maillefer) and randomly divided into 4 groups $(n=12)$ according to the irrigating solution: Control Group, 0.9\% $\mathrm{NaCl}$ (Dermus, Florianópolis, SC, Brazil); Group ${ }^{\mathrm{NaOCI}}$, 1\% NaOCl (Dermus); Group ${ }^{\mathrm{EDTA}}$, 17\% EDTA (Dermus); and Group ${ }^{\mathrm{EDTA}+\mathrm{NaOCI}}$, 17\% EDTA (Dermus) and $1 \% \mathrm{NaOCl}$ (Dermus).

\section{Irrigation System}

The irrigation protocol used for each group was performed with a 22-gauge blunt-end needle (Ibras, São Paulo, SP, Brazil) $2 \mathrm{~mm}$ short of the WL. In each group, root canals were irrigated with $3 \mathrm{~mL}$ of solution for $10 \mathrm{~min}$. After this time, the solution was removed by aspiration and renewed with the same amount for the same time, totalizing $12 \mathrm{~mL}$ of solution $(4 \times 3 \mathrm{~mL})$ and 40 min total time $(4 \times 10 \mathrm{~min})$ in each group. In Group ${ }^{\mathrm{EDTA}+\mathrm{NaOCl}}$, the solutions were alternated every $10 \mathrm{~min}$, starting with 17\% EDTA.

\section{Intracanal Medication}

The canals were dried with absorbent paper points (Dentsply Maillefer) and filled with calcium hydroxide medication (Figs. 1A and 1B). The paste was prepared by mixing $0.712 \mathrm{~g} \mathrm{Ca}(\mathrm{OH})_{2}$ powder (Merck KGaA, Frankfurter, Germany) with $0.4 \mathrm{~mL}$ propyleneglycol. The paste was placed into the canal using a spiral Lentulo (Dentsply, Maillefer)

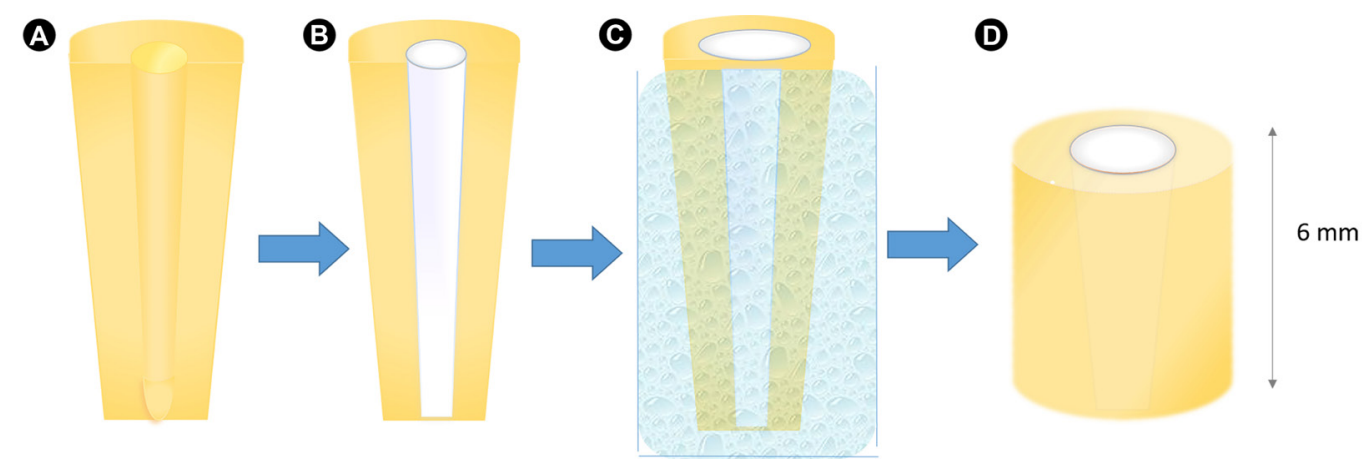

Figure 1. Sequence of sample preparation for compressive strength test. Root canal dry and ready to receive intracanal medication (A). Root canal filled with calcium hydroxide (B). Root canal filled with intracanal medication, sealed with temporary material and stored in 100\% relative humidity for 30 days (C). Cylinders of dentine obtained after cut and exterior waste to standardize thickness (D). 
and radiographs were taken to confirm the complete filling. A provisional 2-mm-thick restoration (Citodur, DoriDent, Vienna, Austria) was placed and the roots were stored in $100 \%$ relative humidity at $37^{\circ} \mathrm{C}$ for 30 days (Fig. 1C).

\section{Compressive Strength}

Each root was sectioned (first cut) $1 \mathrm{~mm}$ below the cemento-enamel junction using a 0.15 diamond saw at slow speed (Isomet 1000; Buehler, Lake Bluff, IL, USA). A second cut was performed $6 \mathrm{~mm}$ apically from the first cut, resulting in $6 \mathrm{~mm}$-long cylinders. The cylinders were polished with smooth sand paper to produce smooth flat ends to prevent any interference with the jaws of the test machine. In order to standardize the cylinder diameter in approximately $3 \mathrm{~mm}$ (Fig. 1D), additional wears were performed using diamond burs (2135 model; KG Sorensen, São Paulo, SP, Brazil) in a high-speed handpiece with air/ water coolant. Then, each dentin cylinder was tested for the compressive force required to fracture it by a universal testing machine (Instron Model 4444; Instron, Canton, MA, USA) at a crosshead speed of $1 \mathrm{~mm} / \mathrm{min}$ (Fig. 2). The samples were placed between the jaws of testing machine and forces

\section{Statistical Analysis}

Data were subjected to normality test by KolmogorovSmirnov and homogeneity test by Levene's. The analysis of variance (ANOVA) was performed with SPSS 19.0 for Windows (SPSS Inc., Chicago, IL) statistical software.

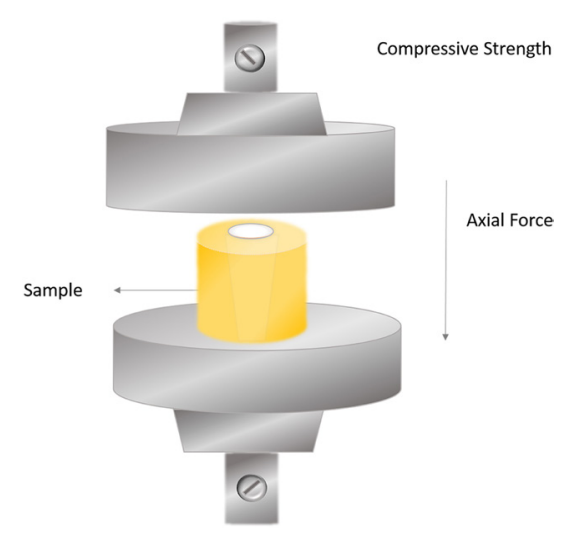

Figure 2. Representation of compressive strength test. The samples were placed between the jaws of testing machine and forces were applied from the coronal end of the cylinder and in a vertical direction.

Post-hoc tests were calculated with Tukey HSD multiple comparison test at $\alpha=0.05$.

\section{Results}

The results obtained after the compressive strength are given in Table 1. There was a significant difference in the compressive strength between groups (one-way ANOVA, $p=0.020$ ). The mean compressive force required to break the samples in the Control Group (151.23 $\pm 94.36 \mathrm{MPa})$, which were irrigated with saline $(\mathrm{NaCl})$, was statistically different from Group ${ }^{\text {EDTA+NaOCI }}(60.12 \pm 92.10 \mathrm{MPa})$ irrigated with $17 \%$ EDTA and 1\% NaOCl (Tukey HSD test, $\mathrm{p}<0.05$ ). However, no statistical difference was observed between Control Group, Group $^{\mathrm{NaOCl}}$ and Group ${ }^{\mathrm{EDTA}}$. In addition, Group ${ }^{\mathrm{NaOCl}}$ was also statistically different $(p<0.05)$ from Group ${ }^{\mathrm{EDTA}+\mathrm{NaOCl}}$ and exhibited a higher mean of compressive strength.

\section{Discussion}

The null hypothesis was rejected based on the results of the study. The use of different irrigating solutions, 30 days before the calcium hydroxide intracanal dressing, promoted statistically significant differences among groups. The present study corroborates other studies in the literature, which observed that the dentin exposure to calcium hydroxide for one month or less, has affected negatively some dentin's mechanical properties $(3,11,16,18)$.

In the present study, the alternate irrigation with EDTA and $\mathrm{NaOCl}$ solutions, prior to calcium hydroxide intracanal dressing, decreased dentin compressive strength. However, when the samples were irrigated with $\mathrm{NaOCl}$ alone, the results were similar to those obtained with saline irrigation (control group). EDTA irrigation alone did not differ significantly from saline irrigation (control group) either, despite the lower compressive strength means. These findings can be justified by the composition, chemical action, alternation and irrigation time with the solutions, as well as the effect of removing the smear layer over calcium hydroxide dressing action.

Regarding the irrigating solutions, it is well known that $\mathrm{NaOCl}$ appears to be the most employed solution due to

Table 1. Compressive strength (MPa, mean \pm standard deviation) values

\begin{tabular}{lc}
\hline Groups and solutions & Compressive strength \\
\hline Control Group: saline & $151.23 \pm 94.36^{\mathrm{a}}$ \\
Group $^{\mathrm{NaOCl}}: 1 \% \mathrm{NaOCl}$ & $167.50 \pm 57.29^{\mathrm{a}}$ \\
Group $^{\mathrm{EDTA}}: 17 \%$ EDTA & $108.79 \pm 99.88^{\text {ab }}$ \\
Group $^{\mathrm{EDTA}+\mathrm{NaOCl}: 17 \% \mathrm{EDTA}, 1 \% \mathrm{NaOCl}}$ & $60.12 \pm 92.10^{\mathrm{b}}$ \\
\hline
\end{tabular}

Different letters indicate statistically significant difference $(\mathrm{p}<0.05)$ between groups (Tukey HSD test). 
its bactericidal activity $(4,5,7,8)$, excellent lubrication (2), ability to dissolve organic components $(1,6)$, bleaching capacity and low surface tension $(1,2)$. However, adverse effects of $\mathrm{NaOCl}$ irrigation on dentin's mechanical properties $(3,10,11,13,19)$ have been reported, including decrease of microhardness (10), flexural strength (11) and elastic modulus (3). Sodium hypochlorite promoted loss of dentinal organic components (19) because this solution is a non-specific proteolytic agent. Organic phase depletion may change mechanical properties (9), due to the fact that dentin has $22 \%$ organic material, especially type I collagen. Collagen plays an important role during dentin structural formation and it is responsible for sustaining dentinal mineral content (19). By losing this organic content, dentinal elastic module and flexural strength decline $(3,10)$.

EDTA is widely used as chelate and cleaning agent during endodontic treatment (1). This solution is able to remove the smear layer and significantly reduce the amount of microorganisms inside the root canal (7). Studies have observed that any irrigating solution is capable of removing both organic and inorganic components from smear layer after canal preparation $(1,2,6)$. Thus, to remove efficiently the smear layer, EDTA is usually recommended, followed by $\mathrm{NaOCl}(6)$.

Nevertheless, this association leads to dentinal tubule orifice opening, intertubular dentinal erosion $(12,20)$ and dentin microhardness reduction (21). When $\mathrm{NaOCl}$ was used alone as an irrigating agent, the exposed inorganic material prevented further dissolution of dentine. However when the solutions are used alternately, both organic and inorganic contents are removed (6). Niu et al. (20) demonstrated that final irrigation with $6 \% \mathrm{NaOCl}$ after treatment with $15 \%$ EDTA causes erosion of peritubular and intertubular dentin. Surface dentin was neither smooth nor flat and dentinal tubule orifices were irregularly enlarged (20).

In the present study, it may be assumed that irrigation time and the $\mathrm{NaOCl}$-EDTA combination might have resulted in a significant root dentin strength decrease compared with the control group. It is important to emphasize that 20 min irrigation with EDTA may have affected the results. EDTA is mostly used only for final irrigation, after canal preparation and for short periods ( 1 to $5 \mathrm{~min}$ ) to remove the smear layer (6). Periods longer than 10 min may cause severe peritubular and intertubular dentinal erosion (12) and dentinal tubule enlargement. When $\mathrm{NaOCl}$ was used after irrigation with EDTA, also for 20 min, changing the solutions at every $10 \mathrm{~min}$, there was a major decrease of dentin strength. The use of EDTA for longer periods (20 to $40 \mathrm{~min}$ ) attempted to simulate its use in atresic canals. In these situations, EDTA is used along all root canal preparation, improving the file actions by lubrication and decalcification of dentin structure $(2,19)$.
Evaluating the impact of using $2.5 \% \mathrm{NaOCl}$ and $17 \%$ EDTA in different sequences on dentin elastic modulus and flexural strength, Marending et al. (11) observed that samples exposed to $\mathrm{NaOCl}$ for 24 min had their flexural strength reduced. However, EDTA used for shorter periods, before or after $\mathrm{NaOCl}$ irrigation, did not affect the outcomes. It is important to remind that those authors (11) employed dentin bars, which remained totally immersed in hypochlorite, while in our study, only the root canal remained in contact with the solutions, although there was alternate irrigation with EDTA for 20 min. This may have led to higher hypochlorite penetration into dentinal tubules, increasing its action and consequently causing more damage to dentinal collagen matrix. Dentin becomes more fragile and brittle when this matrix is destroyed.

Mineral components in hard tissues contribute to their strength and elastic modulus, whereas the organic component is associated with tissue toughness (22). Collagen matrix destruction in mineralized tissue results in a more brittle and friable substratum that can lead to fatigue crack propagation during cyclic stresses (23).

Finally, a greater dentinal tubule opening by smear layer removal may have improved the effects of calcium hydroxide. Although all groups received intracanal medication for the same time, better effects could be achieved in smear-free canals due to higher hydroxyl ion diffusion in dentin (24). The authors choose to use manual instrumentation in order to minimize the presence of untouched canal walls during preparation, which could result in smear layer formation. Furthermore, canal shaping in the cervical and middle thirds were complemented with Gates Glidden drills, which produced circular sections and standardized the amount of calcium hydroxide dressing inside the canal.

It has been suggested that calcium hydroxide could decrease dentin resistance in smear layer absence. Reports have shown that one week of calcium hydroxide medication can damage dentin resistance (3). Andreasen et al. (17) demonstrated that extracted sheep incisors filled with calcium hydroxide for $1 / 2,1,2,3,6,9$, or 12 months had their fracture strength greatly reduced, and this decrease was proportional to the increase of the experimental periods. Sahebi et al. (16) reported that dentin cylinders exposed to calcium hydroxide for 30 days needed a lower compression load to fracture. Zarei et al. (25) observed that under in vitro conditions, teeth with instrumented canals that received calcium hydroxide medication for periods over 1 month had their fracture strength reduced. In shorter periods, resistance also decreased, but it was not statistically significant.

It is also important to highlight that the control group (irrigated with saline) had also the root canal filled with 
calcium hydroxide for 30 days. Therefore, the lack of significant difference between groups irrigated with saline and those irrigated with $\mathrm{NaOCl}$ could be attributed to the fact that none of those solutions is capable of removing the smear layer (2)

Considering our results, final irrigation with EDTA and $\mathrm{NaOCl}$ prior to intracanal medication should be carried out in the shortest irrigation time possible. This could avoid adverse effects over root dentin strength. Furthermore, new studies are needed to observe how irrigation time and amount of solutions, when used in association and prior to intracanal dressing, can affect root dentin mechanical properties.

In conclusion, it was possible to verify that the use of irrigating solutions prior to calcium hydroxide intracanal medication may influence root dentin compressive strength. Canal irrigation with 17\% EDTA followed by $1 \% \mathrm{NaOCl}$ decreased dentin strength significantly, after 30 days on calcium hydroxide dressing.

\section{Resumo}

0 objetivo desse estudo foi avaliar o efeito da irrigação intracanal com hipoclorito de sódio $(\mathrm{NaOCl})$ e ácido etilenodiamino tetracético

₹ (EDTA) previamente à medicação de hidróxido de cálcio na resistência

む à compressão da dentina radicular. Quarenta e oito raízes com canais únicos e retos tiveram os canais instrumentados pela técnica coroa-ápice com limas Flexofile e brocas Gates Glidden sob irrigação com solução salina $(\mathrm{NaCl})$ a $0,9 \%$. Os canais radiculares foram separados em 4 grupos $(n=12)$, de acordo com a solução irrigadora: Grupo Controle, $\mathrm{NaCl} 0,9 \%$; - Grupo ${ }^{\mathrm{NaOCI}}, \mathrm{NaOCl} 1 \%$; Grupo ${ }^{\mathrm{EDTA}}$, EDTA 17\%; e Grupo ${ }^{\mathrm{EDTA}+\mathrm{NaOCI}}, \mathrm{NaOCl}$ 1\% e EDTA 17\%. As soluções permaneceram por $40 \mathrm{~min}$, sendo renovadas a cada $10 \mathrm{~min}$, exceto para o Grupo ${ }^{\mathrm{EDTA}+\mathrm{NaOCl}}$, onde as soluções foram alternadas a cada $10 \mathrm{~min}$. Os canais foram secos, preenchidos com pasta de hidróxido de cálcio e radiografados. Cada canal foi selado e mantido a $37{ }^{\circ} \mathrm{C}$ por 30 dias. Após esse período, as raizes foram cortadas $1 \mathrm{~mm}$ abaixo da junção cemento-esmalte e $6 \mathrm{~mm}$ apicalmente a este corte, a fim de obter cilindros de $6 \mathrm{~mm}$ de comprimento. 0 teste de compressão foi realizado com velocidade de cruzeta de $1 \mathrm{~mm} / \mathrm{min}$. As médias $( \pm S D)$ da

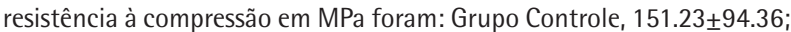
Grupo $^{\mathrm{NaOCl}}, 167.50 \pm 57.25$; Grupo ${ }^{\text {EDTA }}, 108.79 \pm 99.88$; Grupo ${ }^{\text {EDTA+NaOCI }}$ 60.12 \pm 92.10 . Diferenças estatisticamente significativas foram encontradas entre os grupos (ANOVA e Tukey; $\alpha=0,05 ; p=0,02$ ). 0 Grupo Controle e o Grupo ${ }^{\mathrm{NaOCl}}$ obtiveram maiores médias de resistência à compressão

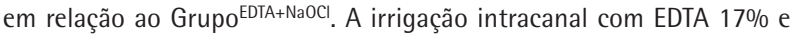
$\mathrm{NaOCl} 1 \%$ promoveu redução significativa da resistência à compressão da dentina, após 30 dias de medicação intracanal com hidróxido de cálcio.

\section{References}

1. Haapasalo M, Shen Y, Wang Z, Gao Y. Irrigation in endodontics. Braz Dental J 2014;21:299-303.

2. Good M, El KI, Hussey DL. Endodontic 'solutions' Part 1: a literature review on the use of endodontic lubricants, irrigants and medicaments. Dent Update 2012;39:239-246.

3. Grigoratos D, Knowles J, Ng YL, Gulabivala K. Effect of exposing dentine to sodium hypochlorite and calcium hydroxide on its flexural strength and elastic modulus. Int Endod J 2001;34:113-119.

4. Christo JE, Zilm PS, Sullivan T, Cathro PR. Efficacy of low concentrations of sodium hypochlorite and low-powered Er,Cr:YSGG laser activated irrigation against an Enterococcus faecalis biofilm. Int Endod J 2016;49:279-286.

5. Soares ZA, Carvalho MAR de; Santos SMC, Mendonça RMC, Ribeiro-
Sobrinho AP, Brito-Junior M, et al.. Effectiveness of chemomechanical preparation with alternating use of sodium hypochlorite and EDTA in eliminating intracanal Enterococcus faecalis biofilm. J Endod 2010;36:894-898.

6. Teixeira CS, Felippe MCS, Felippe WT. The effect of application time of EDTA and $\mathrm{NaOCl}$ on intracanal smear layer removal: an SEM analysis. Int Endod J 2005;38:285-290.

7. Byströn $A$, Sundqvist $G$. The antibacterial action of sodium hypochlorite and EDTA in 60 cases of endodontic therapy. Int Endod J 1985;18:3540.

8. Gonçalves LS, Rodrigues RC, Andrade Junior CV, Soares RG, Vettore MV. The effect of sodium hypochlorite and chlorhexidine as irrigant solutions for root canal disinfection: a systematic review of clinical trials. J Endod 2016;42:527-532.

9. Schmidt TF, Teixeira CS, Felippe MC, Felippe WT, Pashley DH, Bortoluzzi EA. Effect of ultrasonic activation of irrigants on smear layer removal. J Endod 2015;41:1359-1363.

10. Pascon FM, Kantovitz KR, Sacramento PA, Nobre-dos-Santos M, Puppin-Rontani RM (2009). Effect of sodium hypochlorite on dentine mechanical properties. A review. J Dent 2009;37:903-938.

11. Marending $M$, Paqué $F$, Fischer J, Zehnder $M$. Impact of irrigant sequence on mechanical properties of human root dentin. J Endod 2007;33:1325-1328.

12. Çalt $\mathrm{S}$, Serper A. Time-dependent effects of EDTA on dentin structures. J Endod 2002;28:17-19.

13. Ghisi AC, Kopper PM, Baldasso FE, Stürmer CP, Rossi-Fedele G, Steier $\mathrm{L}$, et al.. Effect of super-oxidized water, sodium hypochlorite and EDTA on dentin microhardness. Braz Dent J 2014;25:420-424.

14. Sen BH, Ertürk O, Pişkin B. The effect of different concentrations of EDTA on instrumented root canal walls. Oral Surg Oral Med Oral Pathol Oral 2009;108:622-627.

15. Ozdemir HO, Buzoglu HD, Çalt S, Çehreli ZC, Varol E, Temel A. Chemical and ultramorphologic effects of ethylenediaminetetraacetic acid and sodium hypochlorite in young and old root canal dentin. J Endod 2012;38:204-208.

16. Sahebi S, Moazami F, Abbott P. The effects of short-term calcium hydroxide application on the strength of dentine. Dent Traumatol 2010;26:43-46.

17. Andreasen JO, Farik B, Munksgaard EC. Long-term calcium hydroxide as a root canal dressing may increase risk of root fracture. Dent Traumatol 2002;18:134-137.

18. Yassen $\mathrm{GH}$, Platt, JA. The effect of nonsetting calcium hydroxide on root fracture and mechanical properties of radicular dentine: a systematic review. Int Endod J 2013;46:112-8.

19. Hülsmann $M$, Effects of mechanical instrumentation and chemical irrigation on the root canal dentin and surrounding tissues. Endodontic Topics 2013;29:55-86.

20. Niu W, Yoshioka T, Suda H. A scanning electron microscopic study of dentinal erosion by final irrigation with EDTA and $\mathrm{NaOCl}$ solutions. Int Endod J 2002;35:934-939.

21. Sayin TC, Serper A, Cehreli ZC, Otlu HG. The effect of EDTA, EGTA, EDTAC, and tetracycline- $\mathrm{HCl}$ with and without subsequent $\mathrm{NaOCl}$ treatment on the microhardness of root canal dentin. Oral Surg Oral Medi Oral Pathol Oral Radiol and Endod 2007;104:418-424.

22. Wang $X$, Bank RA, Tekoppele JM, Agrawal CM. The role of collagen in determining bone mechanical properties. J Orthop Res 2001;19:10211026.

23. Kruzic JJ, Ritchie RO. Fatigue of mineralized tissues: cortical bone and dentin. J Mech Behav Biomed Mat 2008;1:3-17.

24. Foster KH, Kulild JC, Weller RN. Effect of smear layer removal on the diffusion of calcium hydroxide through radicular dentin. J Endod 1993;19:136-140.

25. Zarei M, Afkhami F, Poor ZM. Fracture resistance of human root dentin exposed to calcium hydroxide inter-visit medication at various time periods: an in vitro study. Dent Traumatol 2013;29:156-160. 